\title{
Bioaerosols, Noise, and Ultraviolet Radiation Exposures for Municipal Solid Waste Handlers
}

\author{
France Ncube, Esper Jacobeth Ncube, and Kuku Voyi \\ School of Health Systems and Public Health (SHSPH), Faculty of Health Sciences, University of Pretoria, Pretoria, South Africa \\ Correspondence should be addressed to France Ncube; france.ncube257@gmail.com
}

Received 5 October 2016; Accepted 25 December 2016; Published 12 January 2017

Academic Editor: Evelyn O. Talbott

Copyright (C) 2017 France Ncube et al. This is an open access article distributed under the Creative Commons Attribution License, which permits unrestricted use, distribution, and reproduction in any medium, provided the original work is properly cited.

\begin{abstract}
Few studies have investigated the occupational hazards of municipal solid waste workers, particularly in developing countries. Resultantly these workers are currently exposed to unknown and unabated occupational hazards that may endanger their health. We determined municipal solid waste workers' work related hazards and associated adverse health endpoints. A multifaceted approach was utilised comprising bioaerosols sampling, occupational noise, thermal conditions measurement, and field based waste compositional analysis. Results from our current study showed highest exposure concentrations for Gram-negative bacteria $\left(6.8 \times 10^{3} \mathrm{cfu} / \mathrm{m}^{3}\right)$ and fungi $\left(12.8 \times 10^{3} \mathrm{cfu} / \mathrm{m}^{3}\right)$, in the truck cabins. Significant proportions of toxic, infectious, and surgical waste were observed. Conclusively, municipal solid waste workers are exposed to diverse work related risks requiring urgent sound interventions. A framework for assessing occupational risks of these workers must prioritize performance of exposure assessment with regard to the physical, biological, and chemical hazards of the job.
\end{abstract}

\section{Introduction}

Municipal solid waste management is a vital activity in the context of protecting human health and environment [1-3]. Municipal solid waste management workers perform various tasks such as street sweeping [4-6], manually loading waste into waste collection vehicles $[7,8]$ and driving such vehicles [9-11]. Such activities expose these workers to various occupational health risks associated with the characteristics of the waste they handle [12-14], the waste collection methods used [15-17], and the state of the working environment $[8,18-20]$.

Whilst over the past two decades valuable evidence has accumulated on the occupational dust and noise levels in the mining [21-23], manufacturing [24, 25], and agricultural sectors [26-28], very few studies have investigated such hazards for municipal solid waste workers. Of these few studies, the majority of them have been conducted in industrialized countries. The results of epidemiologic studies obtained in developed countries cannot be extrapolated with complete confidence to developing countries [29]. Our study, conducted in a developing country, envisages enriching the existing body of knowledge on hazards of municipal waste handlers.
Additionally, most of these few studies primarily focused on waste recycling plants [30-32], composting plants [3335], and hazardous landfills [36] rather than waste workers responsible for loading municipal solid waste trucks, municipal landfilling operations, central waste collection systems, and street cleansing. Resultantly, very little has been documented on the occupational health risks of municipal solid waste workers. This suggests that such workers are currently exposed to more or less unknown dust, bioaerosols, and noise levels that may endanger their health. Notably a point of congruence among previous studies is the notion that to date little has been done to characterize biological hazards associated with waste collection [15, 37, 38].

It is dust which is in the breathing zone or entering the respiratory system which may pose health risks to the employee and should therefore be assessed and monitored [25]. The impetus to the determination of bioaerosols in the present study is the growing body of evidence in contemporary literature associating bioaerosols from organic dust with respiratory complaints on waste workers [12, 39, 40]. Furthermore, a key recommendation arising from Heida et al. [41] is the need to determine the organic dust concentrations from waste. 
Additionally, assessments of workplace noise exposures are justified on the basis that noise hazards are globally ranked among the top five occupational stressors with grave repercussions on the worker and the organisation [42-44]. Notably, previous literature has strongly associated continuous occupational noise exposures of $85-90 \mathrm{~dB}$ (A) with adverse health conditions on the worker such as Noise Induced Hearing Loss (NIHL) [45, 46]. Liu et al. [47] further propound that the large machinery used to dig, transport, and compact landfills can generate noise level higher than $85 \mathrm{~dB}$.

In both industrialized and developing countries, very little research is available on the thermal conditions in which waste workers work. More importantly, in tropical countries summer outdoor temperatures can be unbearably hot. Such high temperatures may render outdoor activities such as municipal solid waste collection, street sweeping, and landfilling operations a health hazard due to increased risk of excessive sweating, headaches, heat stress, offensive odours, and fly infestation from decomposition processes of organic waste fractions. Conversely, cold outdoor temperatures have been associated with frost bite [48] and hypothermia among gardeners [49].

Consequently this paper aims to determine the occupational dust, noise, and thermal exposures in the field of municipal solid waste management so as to build up the much needed evidence for developing a generic framework for assessing occupational health risks of municipal solid waste handlers.

\section{Materials and Methods}

Personal sampling was performed using two field monitors mounted in the breathing zone of workers, approximately $1.5 \mathrm{~m}$ above ground level. One monitor was for collecting of total dust and the other for bioaerosols (bacteria and fungi). Environmental samples were collected using similar equipment mounted at the breathing zone, from the active landfilling sites, truck cabins, and street cleaning sites. Total dust and bioaerosols samples were collected from various sites (Table 1). Culturing for Gram-negative bacteria (GNB) was done at $37^{\circ} \mathrm{C}$ for 24 hours using the McConkey media whist for viable fungi the Malt Extract Agar media diluted with $0.01 \%$ chloramphenicol was used. The occupational noise exposure doses were measured using the Quest sound level meter model SOUNDPRO SP-DL-1/3n and the ultraviolet thermal conditions were determined using the AZ thermoanemometer instrument. Qualitative data on health complaints of waste workers was gathered using selfadministered questionnaires. Key informant interviews with waste managers in local government structures, in the Health Department and the Environmental Management Agency, were conducted to tap on the richness and diversity of expert input on waste management health risks. Collected data was analyzed using STATA version 13.

\section{Results and Discussion}

3.1. Total Dust and Bioaerosols Exposures. Our study found high mean exposure concentrations for total dust, Gramnegative bacteria (GNB), and fungi for personal samples

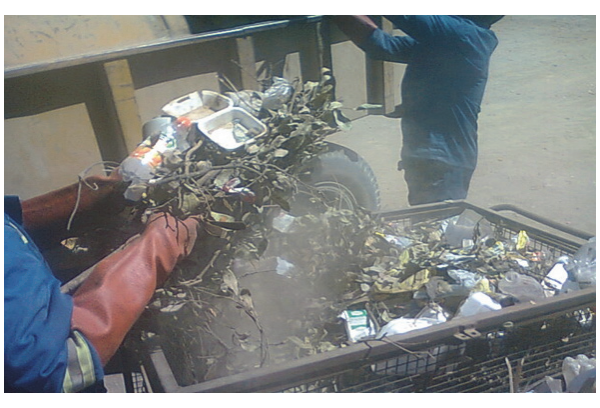

FIGURE 1: Dust generation from loading mixed waste without proper containment bags.

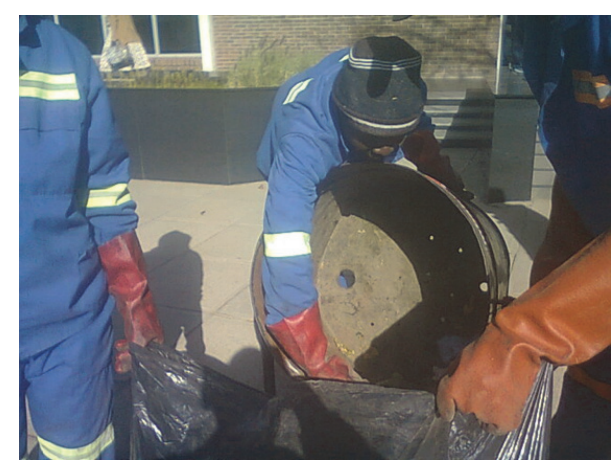

FIGURE 2: Process of transferring of waste from stationery bin to plastic bags.

collected from refuse bin loaders and truck cabin samples (Table 1). This suggests the priority for exposure assessment with regard to total dust and bioaerosols should be focused on waste loaders and the truck cabins. Regular proper cleaning, drying, and aeration of the waste collection vehicle are essential so as to safeguard the respiratory health of waste workers.

The high mean total dust, Gram-negative bacteria (GNB), and fungi exposure concentrations reported in our study for waste loaders and truck cabin may be attributed to the processes of manual offloading and loading of mixed waste streams without proper containment bags (Figure 1).

Our study argues that transferring of waste from stationery bins to other bags (Figure 2) results in almost double exposures to dust and bioaerosols for each refuse collector: firstly during transferring process from one bin to the other and secondly during the bin empting process into the truck.

Nonstationary bins that are directly emptied into the refuse collection truck could avert exposures encountered during the waste bin transferring process. Alternatively, all stationery bin containers may be fitted with removable bin liners that are directly emptied into the waste collection trucks.

Our study found high mean exposure concentrations for total dust, Gram-negative bacteria (GNB), and fungi for personal samples collected from refuse bin loaders and for truck cabin samples (Table 1). Also for all the sampled waste sites concentrations of both Gram-negative bacteria (GNB) 
TABLE 1: Total dust and bioaerosols exposures (mean and range) in different working areas.

\begin{tabular}{|c|c|c|c|c|c|}
\hline Sampling site & Description & $(n)$ & Total dust $\mathrm{mg} / \mathrm{m}^{3}$ & GNB $10^{3} \mathrm{cfu} / \mathrm{m}^{3}$ & Fungi $10^{3} \mathrm{cfu} / \mathrm{m}^{3}$ \\
\hline \multirow{3}{*}{ Site A } & Bin loaders & 12 & $8.2(0.8-26)$ & $1.5(0.16-6.8)$ & $66(7.2-136)$ \\
\hline & Drivers & 4 & $4.2(0.8-12)$ & $1.6(0.2-2.8)$ & $36(6.4-68)$ \\
\hline & Skip bins & 4 & $3.2(0.6-10)$ & $1.2(0.1-6.4)$ & $28(5.8-62)$ \\
\hline Site B & Truck cabin samples & 4 & $8.6(0.9-26)$ & $1.6(0.18-6.8)$ & $68(6.4-12.8)$ \\
\hline \multirow{3}{*}{ Site C } & Site workers & 12 & $0.4(0.2-0.8)$ & $6.8(0.04-28)$ & $3.2(0.4-8.2)$ \\
\hline & Machine operators & 4 & $0.6(1.4-2.2)$ & $22(0.6-120)$ & $21(0.3-100)$ \\
\hline & Site samples & 4 & $0.3(0.1-0.8)$ & $6.2(0.02-24)$ & $2.8(0.2-7.4)$ \\
\hline \multirow{2}{*}{ Site D } & Sweepers & 12 & $0.08(0.04-0.3)$ & ND & $12(14-24)$ \\
\hline & Site samples & 4 & $0.04(0.02-0.5)$ & $\mathrm{ND}$ & $8(12-22)$ \\
\hline
\end{tabular}

ND: none detected; GNB: Gram-negative bacteria; cfu: colony forming units; A: waste collectors; B: truck cabin; C: active landfilling site; D: street cleaning; $n$ : sample size.

and fungi were basically in the order of $10^{3}$. Similarly the available body of research on bioaerosols from municipal solid waste management activities has reported the mean and range of bacterial and fungal cells per $\mathrm{m}^{3}$ of air between the orders of $10^{3}$ and $10^{6}$. Recently, in Copenhagen, Madsen et al. [50] found bacterial cells per cubic meter of air to be in the range of 112 to $4.8 \times 10^{4}$ for waste collector's personal samples and 48 to $2.6 \times 10^{3}$ for truck cab samples.

Park et al. [11] reported exposure levels among Korean waste collectors ranging between $0.13 \times 10^{5}$ and $23.5 \times 10^{5}$ for total viable bacteria and $2.4 \times 10^{4} \mathrm{CFU} / \mathrm{m}^{3}$ and $10.8 \times$ $10^{4} \mathrm{CFU} / \mathrm{m}^{3}$ for fungi. In Norway, Heldal et al. [51] observed slightly higher summer bacterial and fungal exposures for waste collectors $\left(0.4 \times 10^{6}\right.$ cells $/ \mathrm{m}^{3}$ to $3.6 \times 10^{6}$ cells $\left./ \mathrm{m}^{3}\right)$ compared to winter exposures $\left(0.4 \times 10^{6}\right.$ cells $/ \mathrm{m}^{3}$ to $2.0 \times$ $10^{6} \mathrm{cells} / \mathrm{m}^{3}$ ). Lavoie and Dunkerley [37] reported mean bacterial concentrations of $10^{3}$ to $10^{4} \mathrm{CFU} / \mathrm{m}^{3}$ and mean fungal concentrations ranging between $8.3 \times 10^{3} \mathrm{CFU} / \mathrm{m}^{3}$ and $9.8 \times$ $10^{4} \mathrm{CFU} / \mathrm{m}^{3}$, among waste collectors in Canada. In a sample of German waste collectors, Neumann et al. [52] reported bacterial concentrations ranging between insignificant levels and $10^{6} \mathrm{CFU} / \mathrm{m}^{3}$ and fungi concentrations between $8.3 \times$ $10^{3} \mathrm{CFU} / \mathrm{m}^{3}$ and $9.8 \times 10^{4} \mathrm{CFU} / \mathrm{m}^{3}$. Evidently, municipal solid waste handling processes expose waste workers to bioaerosols from organic dust and such exposure may precipitate onset of respiratory problems $[9,12,53]$.

3.2. Noise Exposures. The highest average noise levels (84.86 dBA) were recorded in the central waste collection points whilst the lowest ( $83 \mathrm{dBA})$ was in the cabin of waste collection truck. In all measured waste management sites (Table 2) mean noise levels were within the international threshold limit value ( $85 \mathrm{dBA})$.

However, the major sources of noise were waste collection vehicles' running engines, other traffic and landfilling vehicles. Constituents of municipal solid waste such as glass and metal tins also contributed to the occupational noise particularly during emptying of metal bins on the metal floor of waste collection vehicles. High working speed with regard to offloading of waste bins tended to produce a monotonous noise. Additionally, Jerie [54] observes that, for informal waste workers, sources of noise entail working closer to heavily frequented roads and other noise sources such as carpentry, metal work, and engineering workshops. Unfortunately, all the refuse collection vehicles in the present study had no noise reduction mechanisms such as rubber lined floors.

Our study findings are far below personal noise levels observed in glass waste collection operations (108 to $131 \mathrm{~dB}$ $\mathrm{L}_{\mathrm{AE}}$.) in the United Kingdom [55]. According to Kuijer and Frings-Dresen [17], Stassen and colleagues found personal noise exposure levels as high as $96.4 \mathrm{dBA}$ among waste collectors in the Netherlands. Evidently the noise risk exposure differs per each scenario which suggests the need for each authority responsible for waste management to consider performing its own noise assessments so as to yield relevant data for informing decision making on required interventions.

In the present study we observed that none of the municipal solid waste workers wore any hearing protection devices though two workers in the waste collection crew complained of occasional temporary hearing loss. Whilst our study did not find mean noise levels above recommended levels we suggest that where hearing protection devices are considered as precautionary measures, there is need to consider the possibility of failure to hear warning sounds from other road users which may increase the risk of accidents and injury among waste workers.

3.3. Thermal Conditions. Outdoor work is associated with greater exposure to hot and cold temperatures [49]. In our present study we observed that municipal solid management operations such as street sweeping, landfilling activities, and door to door waste collection are performed in such hot environments, often in unshaded areas. We observed mean summer temperatures higher than $33^{\circ} \mathrm{C}$ in most waste management areas (Table 3).

Temperatures below and above those typically preferred by most people have a significantly detrimental effect on the safety related behavior of workers [56]. This suggests that for optimum promotion of occupational safety behavior of municipal solid waste workers the thermal working environment requires attention by responsible authorities. In our present study we observed that most waste workers 
TABLE 2: Noise level measurements (dBA) in various working areas.

\begin{tabular}{llcc}
\hline Site & Site description & Average noise value (dBA) & ISO standard (dBA) \\
\hline A & $\begin{array}{l}\text { Noise mainly generated by hydraulic waste collection trucks and passing traffic. } \\
\text { B }\end{array} \quad \begin{array}{l}\text { Waste spreading in cells and soil cover application. Noise generated by waste } \\
\text { compactors. }\end{array}$ & 84.86 & 85.32 \\
C $\quad \begin{array}{l}\text { Manual offloading of waste bins into waste collection vehicles. Noise mainly } \\
\text { generated by hydraulic waste collection trucks and passing traffic. }\end{array}$ & 83.00 \\
\hline
\end{tabular}

A: central collection points, B: active landfilling area, and C: offloading area into truck.

TABLE 3: Summer thermal conditions measured in various waste sites.

\begin{tabular}{lcl}
\hline Work site & Average $T^{\circ} \mathrm{C}$ & Waste workers' concerns \\
\hline Loading waste collection vehicles & 33.34 & Sweating, dehydration, heat syncope, and heat exhaustion. \\
\hline Street and open areas sweeping & 33.28 & $\begin{array}{l}\text { Loss of concentration. } \\
\text { High risk of being run over by traffic, sweating, dehydration, and headache. }\end{array}$ \\
\hline Manning waste disposal sites & 33.29 & $\begin{array}{l}\text { Offensive odours and high fly infestation from increased organic, sweating, heat stress, } \\
\text { and headaches. }\end{array}$ \\
\hline Driving waste collection vehicles & 26.25 & Sweating and occasional headache. \\
\hline
\end{tabular}

complained of headaches, sunburn, heat stress, excessive sweating, dehydration, and difficulties in concentration in assigned tasks. Notably difficulties in concentration may increase the risk of being run over not only by waste collection vehicles but also by other traffic especially during the day when the traffic volume is high. Inhalation of toxic emissions like carbon monoxide and carbon diode from traffic exhausts pipes may further exacerbate the situation. This suggests the need for waste managers, particularly in tropical countries, to consider rescheduling summer waste collection services for early morning hours or at night when temperatures are cooler and low and traffic volume low. Additionally, waste workers need to be encouraged to take regular breaks and rest in cooler shades where oral rehydration fluids can be given to refresh them.

3.4. Other Hazards. The current study found that on average the monthly total amount waste collected in the study area, in tones, was on average 566.08 of which 518.88 was from residential suburbs, 18.88 was from commercial enterprises, and 28.32 was from industries. Results from the physical waste compositional analysis revealed that residential waste on average constituted $24 \%$ food waste, metal containers $4 \%$, glass and ceramics $2 \%$, diapers $2 \%$, toxic waste streams $1 \%$, plastics and paper $13 \%$, and $54 \%$ miscellaneous waste streams. The commercial waste stream was mainly dominated by food waste $42 \%$, metal tins containers $24 \%$, glass $1 \%$, paper and plastics $7 \%$, and other waste streams $24 \%$. Evidently wastes from both the residential and commercial sources had significant proportions of biodegradable food waste. Biodegradation of such organic waste produces offensive odours and supports fly breeding and infestation particularly in summer when temperature is high. The presence of diapers, though in small proportions, in residential waste is a cause of concern since this poses risks of transmission of pathogenic organisms into waste workers' hands. Waste from the industries was mainly scrap metals, rumble, glass, and food remains.
3.5. Hazardous Waste Streams. Results from the present study revealed that the major toxic waste streams in municipal solid waste included hair sprays, shampoos, expired medicines, pesticides and e-waste, shoe and floor polish, carpet and furniture cleaning agents, motor vehicle brake fluid, battery acid, and nail paints. Although available in small quantities (1\%), toxic waste inevitably renders the entire municipal solid waste potentially toxic and can lead to various occupational health risks for waste collectors through inhalation, ingestion, and dermal exposure pathways. Pesticide residues such as organophosphates could affect the central nervous system through inhibition of the choline esterase enzyme. In the present study we observed discarded pesticide containers in household waste streams which could be a source of arsenic exposures for waste workers. The International Agency on Research on Cancer [57] categorises arsenic as a known human carcinogen.

Arsenic can lead to cellular toxicity [58-60], neurotoxicity [56, 61], immunotoxicity [62], cardiovascular diseases [57], and developmental and reproductive toxicity [61, 63, 64]. Additionally, our study reports e-waste streams in household municipal solid waste streams.

The major e-waste components found in the present study include fluorescent and nonfluorescent bulbs, circuit boards, lead and acid car batteries, printer inks and tonner, spark plugs, motherboards, keyboards, monitors, electrical switches, and thermostats. Fluorescent and nonfluorescent bulbs, circuit boards, and car batteries in municipal solid can be source of lead $(\mathrm{Pb})$ and mercury $(\mathrm{Mg})$. Similarly, inks and tonner for printers and $\mathrm{NiCd}$ rechargeable batteries can be a source of cadmium (Cd). Also, monitors and keyboards in municipal solid waste streams are a cause of concern since they can be primary sources of polyvinyl chlorides (PVC) which may emit harmful gaseous substances such as hydrogen chloride gas.

Previous literature has associated lead $(\mathrm{Pb})$, cadmium (Cd), mercury (Mg), and polyvinyl chlorides from e-waste with various adverse mental health effects such as cognitive 


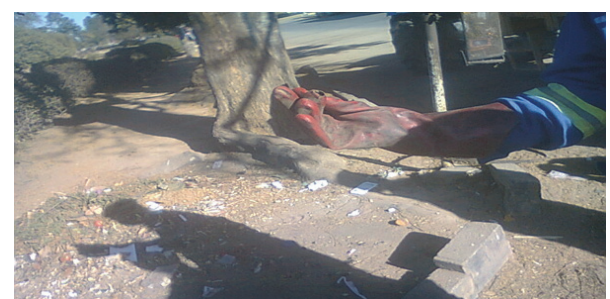

FIGURE 3: Waste collector wearing nonpuncture-proof and worn out gloves.

disturbances and reduced intelligence quotient (IQ) [6569]. Most of these chemicals from e-waste have been found to heavily contaminate ambient air $[68,70,71]$. Such high ambient air concentrations of toxic e-waste chemicals could lead to relatively high inhalational exposures for waste workers. This suggests the need for waste managers to periodically conduct exposure monitoring for waste workers and engage the generators of hazardous waste in efforts such as extended producer responsibility in sound waste management, Life Cycle Analysis (LCA), and regulatory compliance. Table 4 summarises the observed hazardous waste streams and potential occupational risks for municipal solid waste workers for the current study.

Results from the physical waste compositional analysis revealed considerable proportions of infectious materials in municipal solid waste (2\%), such as diapers and used tissue (Table 4). Contact with such contaminated materials may contribute to transmission of faecal-oral diseases such as hepatitis A. Previous work has richly detailed the hepatitis A (HAV) risk associated with waste management. In Greece, Dounias and Rachiotis [72] observed a significantly increased prevalence of HAV infection among solid waste collectors and suggested among other measures vaccination of waste workers against HAV.

Our study found relatively high levels of mechanical waste components such as scrap metal, broken glass, and razor blades (Table 4). Such components have potential to inflict physical harm to municipal solid waste workers in form of cuts, open wounds, and bruises. Although gloves were provided for waste workers, they were not punctureproof and were worn out (Figure 3). In light of epidemiologic evidence linking hepatitis B and needle stick injury [73], such an unhealthy status of waste workers' gloves is a cause of concern. Tsovili et al. [73] found significantly higher prevalence of hepatitis B virus infection $(p<0.01)$ in waste collectors (15\%) in comparison with the control group (2.5\%). Thus municipal solid waste collection is a job heavily laden with biological risks that may endanger waste workers' health.

3.6. Strengths and Limitations. Our paper presents the strength of the inclusion of occupational hygiene measurements related to several occupational hazards. Particularly, bioaerosols exposure determination, occupational noise, and thermal conditions measurement were done. However we did not measure exposures through other routes such as hand contact with contaminated materials. Thus our study is unable to estimate the microbiological risk through the ingestion route since we did not swab waste workers' hands and nails to determine the remaining concentrations of $E$. coli and faecal after washing their hands. Nonetheless since results from our physical waste compositional analysis revealed faecal waste (diapers) in municipal solid waste streams (Table 4), waste workers may be at risk of faecal-oral transmitted diseases through contaminated hands following handling of such waste materials. Therefore, further studies may need to determine the efficiency of hand washing methods utilised by municipal solid waste workers.

To the best of our knowledge, very limited studies have been conducted on the GNB and fungi exposure concentrations at municipal solid waste management sites such as active landfilling sites, refuse bin collection points, and truck cabins. Our study enriches and broadens the existing body of knowledge in this negated area (Table 4). Moreover, our findings have positive implications on the planning and conduction of municipal solid waste collection activities. Some proposed changes include rescheduling summer waste collection for early morning or at night when temperatures are cooler, provision of resting shades, and oral rehydration fluids to cushion waste workers from heat exhaustion and syncope.

Other shortcomings of our current study entail usage of relatively small samples sizes (Table 1) and a cross-sectional study which may limit our findings with regard to proving causality relationships and extrapolating our results to the wider population of municipal solid waste workers.

\section{Conclusion}

Our study found high mean exposure concentrations for total dust, Gram-negative bacteria (GNB), and fungi for personal samples collected from refuse bin loaders and for truck cabin samples. This suggests the priority for exposure assessment with regard to total dust and bioaerosols should be focused on waste loaders and the truck cabins. Also, we observed mean summer temperatures higher than $33^{\circ} \mathrm{C}$ in most waste management areas and workers complained of headaches, sunburn, heat stress, excessive sweating, dehydration, and difficulties in concentration in assigned tasks. Consequently our study argues that in tropical countries it is better to perform summer waste collection services in early morning hours or at night when temperatures are cooler. Waste workers should be encouraged to take regular breaks and rest in cooler shades where oral rehydration fluids can be given to refresh them. In light of the results from our physical waste compositional analysis, our study concludes that municipal solid waste workers are exposed to diverse toxic, mechanical, and infectious hazards requiring sound mitigation measures.

\section{Ethical Approval}

Approval of the University of Pretoria Faculty of Health Sciences' Ethics Committee was obtained and the Ethics Reference Number is 343/2014. Approval from the study area's town council was received in writing. A two-way dialogue was held with all the study participants where the purposes and procedures of the study were discussed and 
TABLE 4: Household hazardous waste compositional analysis and associated hazards.

\begin{tabular}{lll}
\hline Waste type & Components & Potential hazards for waste handlers \\
\hline \multirow{2}{*}{ Toxic (1\%) } & $\begin{array}{l}\text { Hair sprays, lotions, shampoos, expired medicines, and } \\
\text { pesticides } \\
\text { E-waste (e.g., fluorescent bulbs, car batteries, printer } \\
\text { ink, and tonner) }\end{array}$ & $\begin{array}{l}\text { This can lead to systemic intoxication from inhalational } \\
\text { exposures. This can also lead to severe burns from } \\
\text { accidental or spontaneous ignition of flammable materials. } \\
\text { Toxic metals in e-waste may damage target organs leading } \\
\text { to various toxicity effects. }\end{array}$ \\
\hline \multirow{2}{*}{$\begin{array}{l}\text { Infectious (2\%) } \\
\text { Mechanical hazards }\end{array}$} & $\begin{array}{l}\text { Infectious waste can transmit bacteria responsible for } \\
\text { spreading diarrhoeal diseases. Biodegradation of faecal } \\
\text { matter in diapers generates offensive odours that can } \\
\text { induce anorexia, nausea, and vomiting. }\end{array}$ \\
\hline
\end{tabular}

Average $\%$ by weight calculated per weekly waste generation rates.

all participating workers voluntarily signed informed consent with the full rights to withdraw from the study without having to give any excuse. No samples of blood or body fluids were collected from participants in this study. Where images of workers were used deliberate attempts are taken to hide the facial appearance of workers and all data collected was treated with utmost confidentiality and the anonymity of respondents was greatly respected.

\section{Disclosure}

The paper was presented at the Public Health Practitioners Association (PHASA) Conference of South Africa, held in the period 19-22 September 2016, but is not under consideration for publication in any journal.

\section{Competing Interests}

The authors declare that there is no conflict of interests regarding the publication of this paper.

\section{References}

[1] M. Medina, "Serving the unserved: informal refuse collection in Mexico," Waste Management and Research, vol. 23, no. 5, pp. 390-397, 2005.

[2] S. Jerie, "Analysis of institutional solid waste management in Gweru, Zimbabwe," Eastern Africa Social Science Research Review, vol. 22, no. 1, pp. 103-125, 2006.

[3] E. A. Da Silveira, M. L. Robazzi, and M. A. Luis, "Street cleaners: occupational accidents in the city of Ribeirão Preto, State of São Paulo, Brazil," Revista Latino-Americana de Enfermagem, vol. 6, no. 1, pp. 71-79, 1998.

[4] L. Giusti, "A review of waste management practices and their impact on human health," Waste Management, vol. 29, no. 8, pp. 2227-2239, 2009.

[5] S. D. Yogesh and S. P. Zodpey, "Respiratory morbidity among street sweepers working at Hanumannagar Zone of Nagpur Municipal Corporation, Maharashtra," Indian Journal of Public Health, vol. 52, no. 3, pp. 147-149, 2008.

[6] A. A. Ewis, M. A. Rahma, E. S. Mohamed et al., "Occupational health-related morbidities among street sweepers and waste collectors at Beni-Suef, Egypt," Egyptian Journal of Occupational Medicine, vol. 37, no. 1, pp. 79-94, 2013.
[7] U. I. Ivens, J. H. Lassen, B. S. Kaltoft, and T. Skov, "Injuries among domestic waste collectors," American Journal of Industrial Medicine, vol. 33, no. 2, pp. 182-189, 1998.

[8] C.-Y. Yang, W.-T. Chang, H.-Y. Chuang, S.-S. Tsai, T.-N. Wu, and F.-C. Sung, "Adverse health effects among household waste collectors in Taiwan," Environmental Research, vol. 85, no. 3, pp. 195-199, 2001.

[9] E. M. Nielsen, B. H. Nielsen, and N. O. Breum, "Occupational bioaerosol exposure during collection of household waste," Annals of Agricultural and Environmental Medicine, vol. 1, no. 10, pp. 53-59, 1995.

[10] P. P. F. M. Kuijer, B. Visser, and H. C. G. Kemper, "Job rotation as a factor in reducing physical workload at a refuse collecting department," Ergonomics, vol. 42, no. 9, pp. 1167-1178, 1999.

[11] D.-U. Park, S.-H. Ryu, S.-B. Kim, and C.-S. Yoon, "An assessment of dust, endotoxin, and microorganism exposure during waste collection and sorting," Journal of the Air \& Waste Management Association, vol. 61, no. 4, pp. 461-468, 2011.

[12] I. M. Wouters, S. K. M. Hilhorst, P. Kleppe et al., "Upper airway inflammation and respiratory symptoms in domestic waste collectors," Occupational and Environmental Medicine, vol. 59, no. 2, pp. 106-112, 2002.

[13] K. K. Heldal and W. Eduard, "Associations between acute symptoms and bioaerosol exposure during the collection of household waste," American Journal of Industrial Medicine, vol. 46, no. 3, pp. 253-260, 2004.

[14] G. Rachiotis, D. Papagiannis, E. Thanasias, G. Dounias, and C. Hadjichristodoulou, "Hepatitis A virus infection and the waste handling industry: A Seroprevalence Study," International Journal of Environmental Research and Public Health, vol. 9, no. 12, pp. 4498-4503, 2012.

[15] O. M. Poulsen, N. O. Breum, N. Ebbehøj et al., "Collection of domestic waste. Review of occupational health problems and their possible causes," Science of the Total Environment, vol. 170, no. 1-2, pp. 1-19, 1995.

[16] B. Schibye, K. Søgaard, D. Martinsen, and K. Klausen, "Mechanical load on the low back and shoulders during pushing and pulling of two-wheeled waste containers compared with lifting and carrying of bags and bins," Clinical Biomechanics, vol. 16, no. 7, pp. 549-559, 2001.

[17] P. P. F. M. Kuijer and M. H. W. Frings-Dresen, "World at work: refuse collectors," Occupational \& Environmental Medicine, vol. 61, no. 3, pp. 282-286, 2004. 
[18] H. An, J. Englehardt, L. Fleming, and J. Bean, "Occupational health and safety amongst municipal solid waste workers in Florida," Waste Management \& Research, vol. 17, no. 5, pp. 369377, 1999.

[19] S. Dorevitch and D. Marder, "Occupational hazards of municipal solid waste workers," Occupational Medicine, vol. 16, no. 1, pp. 125-133, 2001.

[20] H. R. Perez, A. L. Frank, and N. J. Zimmerman, "Health effects associated with organic dust exposure during the handling of municipal solid waste," Indoor and Built Environment, vol. 15, no. 3, pp. 207-212, 2006.

[21] A. K. Mukherjee, S. K. Bhattacharya, and H. N. Saiyed, "Assessment of respirable dust and its free silica contents in different Indian coalmines," Industrial Health, vol. 43, no. 2, pp. 277-284, 2005.

[22] C. Sensogut, "Occupational noise in mines and its control-a case study," Polish Journal of Environmental Studies, vol. 16, no. 6, pp. 939-942, 2007.

[23] A. L. Edwards, J. J. Dekker, R. M. Franz, T. Van Dyk, and A. Banyini, "Profiles of noise exposure levels in South African mining," The Journal of the Southern African Institute of Mining and Metallurgy, vol. 111, no. 5, pp. 315-322, 2011.

[24] O. S. Oyedepo and A. A. Saadu, "Assessment of noise level in sundry processing and manufacturing industries in Ilorin metropolis, Nigeria," Environmental Monitoring and Assessment, vol. 162, no. 1-4, pp. 453-464, 2010.

[25] A. Kanda, C. Masike, and F. Ncube, "Assessment of occupational exposure to airborne particulates otherwise not classifiable at an iron and steel industry in Zimbabwe," Ethiopian Journal of Environmental Studies \& Management, vol. 8, no. 1, pp. 810-815, 2015.

[26] S. Spaan, I. M. Wouters, I. Oosting, G. Doekes, and D. Heederik, "Exposure to inhalable dust and endotoxins in agricultural industries," Journal of Environmental Monitoring, vol. 8, no. 1, pp. 63-72, 2006.

[27] L. Solecki, "Characteristics of annual exposure to noise among private farmers on family farms of mixed-production profile," Annals of Agricultural and Environmental Medicine, vol. 13, no. 1, pp. 113-118, 2006.

[28] J. C. F. Mirembo, A. J. Swanepoel, and D. Rees, "Respirable quartz exposure on two medium-sized farms in southern Mozambique," International Journal of Occupational and Environmental Health, vol. 19, no. 2, pp. 113-118, 2013.

[29] J. Wichmann and K. V. V. Voyi, "Air pollution epidemiologic studies in South Africa-need for freshening up," Reviews on Environmental Health, vol. 20, no. 4, pp. 265-301, 2005.

[30] N. O. Breum, H. Würtz, U. Midtgaard, and N. Ebbehøj, "Dustiness and bio-aerosol exposure in sorting recyclable paper," Waste Management and Research, vol. 17, no. 2, pp. 100-108, 1999.

[31] I.-L. Engkvist, "Working conditions at recycling centres in Sweden-physical and psychosocial work environment," Applied Ergonomics, vol. 41, no. 3, pp. 347-354, 2010.

[32] F. Auler, A. T. A. Nakashima, and R. K. N. Cuman, "Health conditions of recyclable waste pickers," Journal of Community Health, vol. 39, no. 1, pp. 17-22, 2014.

[33] D. Hryhorczuk, L. Curtis, P. Scheff et al., "Bioaerosol emissions from a suburban yard waste composting facility," Annals of Agricultural and Environmental Medicine, vol. 8, no. 2, pp. 177$185,2001$.
[34] L. Fracchia, S. Pietronave, M. Rinaldi, and M. G. Martinotti, "The assessment of airborne bacterial contamination in three composting plants revealed site-related biological hazard and seasonal variations," Journal of Applied Microbiology, vol. 100, no. 5, pp. 973-984, 2006.

[35] A. Albrecht, R. Witzenberger, U. Bernzen, and U. Jäckel, “Detection of airborne microbes in a composting facility by cultivation based and cultivation-independent methods," Annals of Agricultural and Environmental Medicine, vol. 14, no. 1, pp. 81-85, 2007.

[36] K. H. Gelberg, "Health study of New York City department of Sanitation landfill employees," Journal of Occupational and Environmental Medicine, vol. 39, no. 11, pp. 1103-1110, 1997.

[37] J. Lavoie and C. J. Dunkerley, "Assessing waste collectors' exposure to bioaerosols," Aerobiologia, vol. 18, no. 3, pp. 277$285,2002$.

[38] F. Ncube, E. J. Ncube, and K. Voyi, "A systematic critical review of epidemiological studies on public health concerns of municipal solid waste handling," Perspectives in Public Health, 2016.

[39] J. Bünger, M. Antlauf-Lammers, T. G. Schulz et al., "Health complaints and immunological markers of exposure to bioaerosols among biowaste collectors and compost workers," Occupational and Environmental Medicine, vol. 57, no. 7, pp. 458-464, 2000.

[40] T. Gladding, J. Thorn, and D. Stott, "Organic dust exposure and work-related effects among recycling workers," American Journal of Industrial Medicine, vol. 43, no. 6, pp. 584-591, 2003.

[41] H. Heida, F. Bartman, and S. C. van der Zee, "Occupational exposure and indoor air quality monitoring in a composting facility," American Industrial Hygiene Association Journal, vol. 56, no. 1, pp. 39-43, 1995.

[42] S. Melamed, S. Rabinowitz, and M. S. Green, "Noise exposure, noise annoyance, use of hearing protection devices and distress among blue-collar workers," Scandinavian Journal of Work, Environment and Health, vol. 20, no. 4, pp. 294-300, 1994.

[43] B. D. Simpson, R. S. Bolia, R. L. McKinley, and D. S. Brungart, "The impact of hearing protection on sound localization and orienting behavior," Human Factors, vol. 47, no. 1, pp. 188-198, 2005.

[44] Y.-H. Choi and K. Kim, "Noise-induced hearing loss in Korean workers: co-exposure to organic solvents and heavy metals in nationwide industries," PLOS ONE, vol. 9, no. 5, Article ID e97538, 2014.

[45] H. O. Ahmed, J. H. Dennis, O. Badran et al., "Occupational noise exposure and hearing loss of workers in two plants in eastern Saudi Arabia," Annals of Occupational Hygiene, vol. 45, no. 5, pp. 371-380, 2001.

[46] S.-J. Chang, C.-J. Chen, C.-H. Lien, and F.-C. Sung, "Hearing loss in workers exposed to toluene and noise," Environmental Health Perspectives, vol. 114, no. 8, pp. 1283-1286, 2006.

[47] Y. Liu, H. Wang, S. Weng et al., "Occupational hearing loss among Chinese municipal solid waste landfill workers: a crosssectional study," PLOS ONE, vol. 10, no. 6, Article ID e0128719, 2015.

[48] K. Rodahl, "Occupational health conditions in extreme environments," Annals of Occupational Hygiene, vol. 47, no. 3, pp. 241-252, 2003.

[49] L. D. Knibbs, "Occupational hazards to the health of professional gardeners," International Journal of Environmental Health Research, vol. 24, no. 6, pp. 580-589, 2014. 
[50] A. M. Madsen, T. Alwan, A. Ørberg, K. Uhrbrand, and M. B. Jørgensen, "Waste workers' exposure to airborne fungal and bacterial species in the truck cab and during waste collection," Annals of Occupational Hygiene, vol. 60, no. 6, pp. 651-668, 2016.

[51] K. Heldal, W. Eduard, and M. Bergum, "Bioaerosol exposure during handling of source separated household waste," Annals of Agriculture and Environmental Medicine, vol. 4, no. 1, pp. 4551, 1997.

[52] H.-D. Neumann, J. Balfanz, G. Becker, M. Lohmeyer, W. Mathys, and M. Raulf-Heimsoth, "Bioaerosol exposure during refuse collection: results of field studies in the real-life situation," Science of the Total Environment, vol. 293, no. 1-3, pp. 219-231, 2002.

[53] J. Douwes, I. Wouters, H. Dubbeld et al., "Upper airway inflammation assessed by nasal lavage in compost workers: a relation with bio-aerosol exposure," American Journal of Industrial Medicine, vol. 37, no. 5, pp. 459-468, 2000.

[54] S. Jerie, "Occupational risks associated with solid waste management in the informal sector of Gweru, Zimbabwe," Journal of Environmental and Public Health, vol. 2016, Article ID 9024160, 14 pages, 2016.

[55] HSE, Reducing Risks from 'Kerbside' Glass Collection, Health and Safety Executive, 2013.

[56] J. D. Ramsey, C. L. Burford, M. Y. Beshir, and R. C. Jensen, "Effects of workplace thermal conditions on safe work behavior," Journal of Safety Research, vol. 14, no. 3, pp. 105-114, 1983.

[57] International Agency for Research on Cancer, IARC Monographs on the Evaluation of Carcinogenic Risks to Humans: Some Drinking-water Disinfectants and Contaminants, Including Arsenic, vol. 84, IARC, 2004.

[58] S. Ying, K. Myers, S. Bottomley, T. Helleday, and H. E. Bryant, "BRCA2-dependent homologous recombination is required for repair of Arsenite-induced replication lesions in mammalian cells," Nucleic Acids Research, vol. 37, no. 15, pp. 5105-5113, 2009.

[59] A. D. Kligerman, S. I. Malik, and J. A. Campbell, "Cytogenetic insights into DNA damage and repair of lesions induced by a monomethylated trivalent arsenical," Mutation Research/Genetic Toxicology and Environmental Mutagenesis, vol. 695, no. 1-2, pp. 2-8, 2010.

[60] A. Mudhoo, S. K. Sharma, V. K. Garg, and C.-H. Tseng, "Arsenic: an overview of applications, health, and environmental concerns and removal processes," Critical Reviews in Environmental Science and Technology, vol. 41, no. 5, pp. 435-519, 2011.

[61] International Programme for Chemical Safety, "Arsenic and arsenic compounds," Environmental Health Criteria Document 224, International Programme for Chemical Safety, 2001.

[62] T. Sakurai, C. Kojima, M. Ochiai, T. Ohta, and K. Fujiwara, "Evaluation of in vivo acute immunotoxicity of a major organic arsenic compound arsenobetaine in seafood," International Immunopharmacology, vol. 4, no. 2, pp. 179-184, 2004.

[63] N. Sohel, M. Vahter, M. Ali et al., "Spatial patterns of fetal loss and infant death in an arsenic-affected area in Bangladesh," International Journal of Health Geographics, vol. 9, article 53, 2010.

[64] D. Chakraborti, M. K. Senguptu, M. M. Rahaman et al., "Groundwater arsenic contamination and its health effects in the Ganga-Meghna-Brahmaputra plain," Journal of Environmental Monitoring, vol. 6, pp. 74N-83N, 2004.

[65] K. N. Dietrich, O. G. Berger, P. A. Succop, P. B. Hammond, and R. L. Bornschein, "The developmental consequences of low to moderate prenatal and postnatal lead exposure: intellectual attainment in the cincinnati lead study cohort following school entry," Neurotoxicology and Teratology, vol. 15, no. 1, pp. 37-44, 1993.

[66] L. Piikivi, H. Hanninen, T. Martelin, and P. Mantere, "Psychological performance and long-term exposure to mercury vapors," Scandinavian Journal of Work, Environment and Health, vol. 10, no. 1, pp. 35-41, 1984.

[67] D. A. Axelrad, D. C. Bellinger, L. M. Ryan, and T. J. Woodruff, "Dose-response relationship of prenatal mercury exposure and IQ: an integrative analysis of epidemiologic data," Environmental Health Perspectives, vol. 115, no. 4, pp. 609-615, 2007.

[68] Y. Li, X. Xu, K. Wu et al., "Monitoring of lead load and its effect on neonatal behavioral neurological assessment scores in Guiyu, an electronic waste recycling town in China," Journal of Environmental Monitoring, vol. 10, no. 10, pp. 1233-1238, 2008.

[69] G. Zhao, Z. Wang, M. H. Dong et al., "PBBs, PBDEs, and PCBs levels in hair of residents around e-waste disassembly sites in Zhejiang Province, China, and their potential sources," Science of the Total Environment, vol. 397, no. 1-3, pp. 46-57, 2008.

[70] W. J. Deng, J. S. Zheng, X. H. Bi, J. M. Fu, and M. H. Wong, "Distribution of PBDEs in air particles from an electronic waste recycling site compared with Guangzhou and Hong Kong, South China," Environment International, vol. 33, no. 8, pp. 1063-1069, 2007.

[71] N. N. Ha, T. Agusa, K. Ramu et al., "Contamination by trace elements at e-waste recycling sites in Bangalore, India," Chemosphere, vol. 76, no. 1, pp. 9-15, 2009.

[72] G. Dounias and G. Rachiotis, "Prevalence of hepatitis A virus infection among municipal solid-waste workers," International Journal of Clinical Practice, vol. 60, no. 11, pp. 1432-1436, 2006.

[73] E. Tsovili, G. Rachiotis, E. K. Symvoulakis et al., "Municipal waste collectors and hepatitis B and C virus infection: a crosssectional study," Infezioni in Medicina, vol. 22, no. 4, pp. 271-276, 2014. 


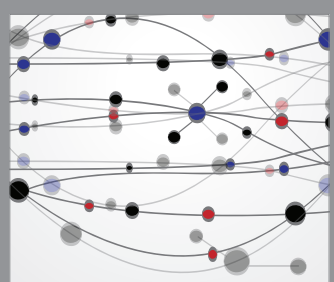

The Scientific World Journal
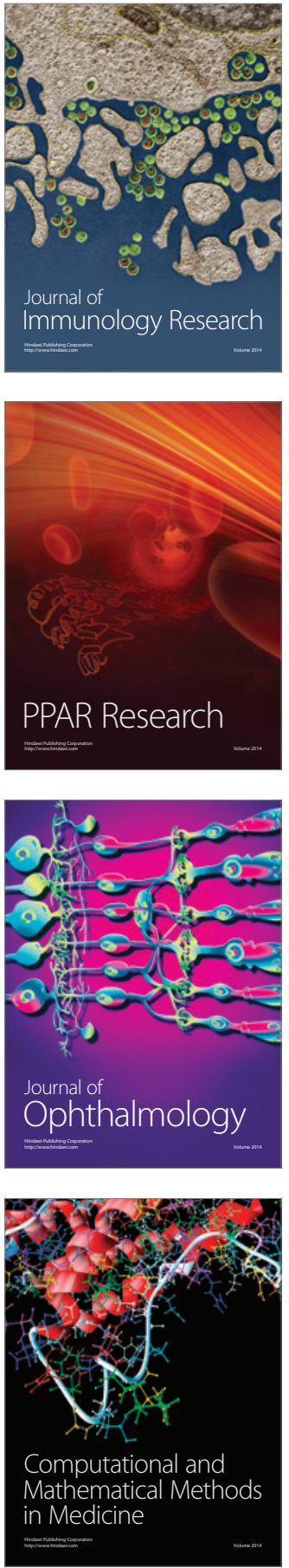

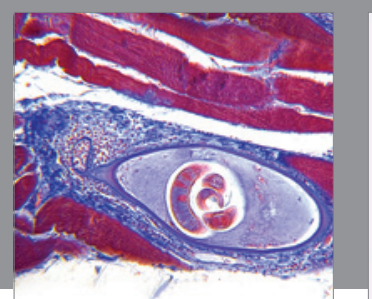

Gastroenterology Research and Practice
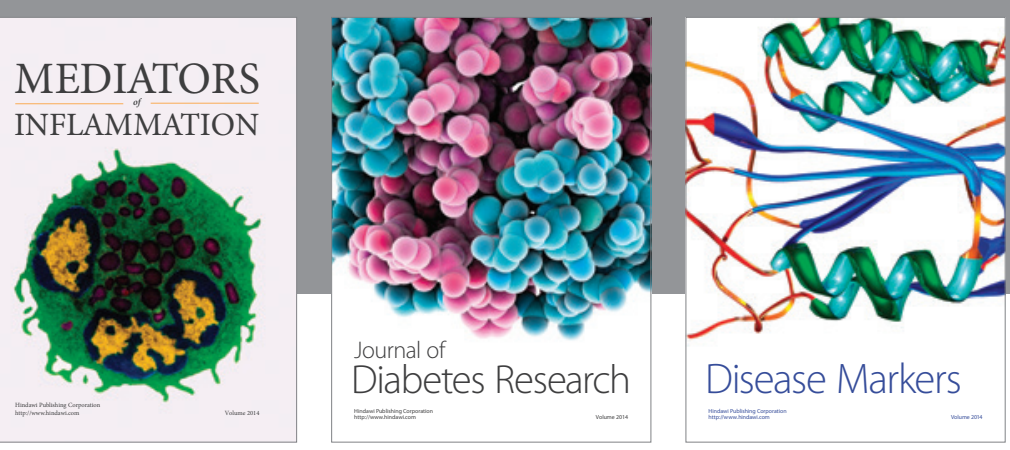

Disease Markers

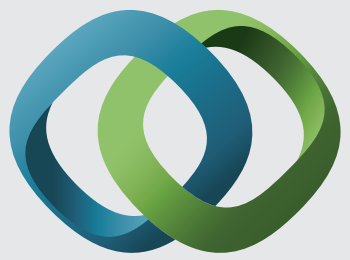

\section{Hindawi}

Submit your manuscripts at

https://www.hindawi.com
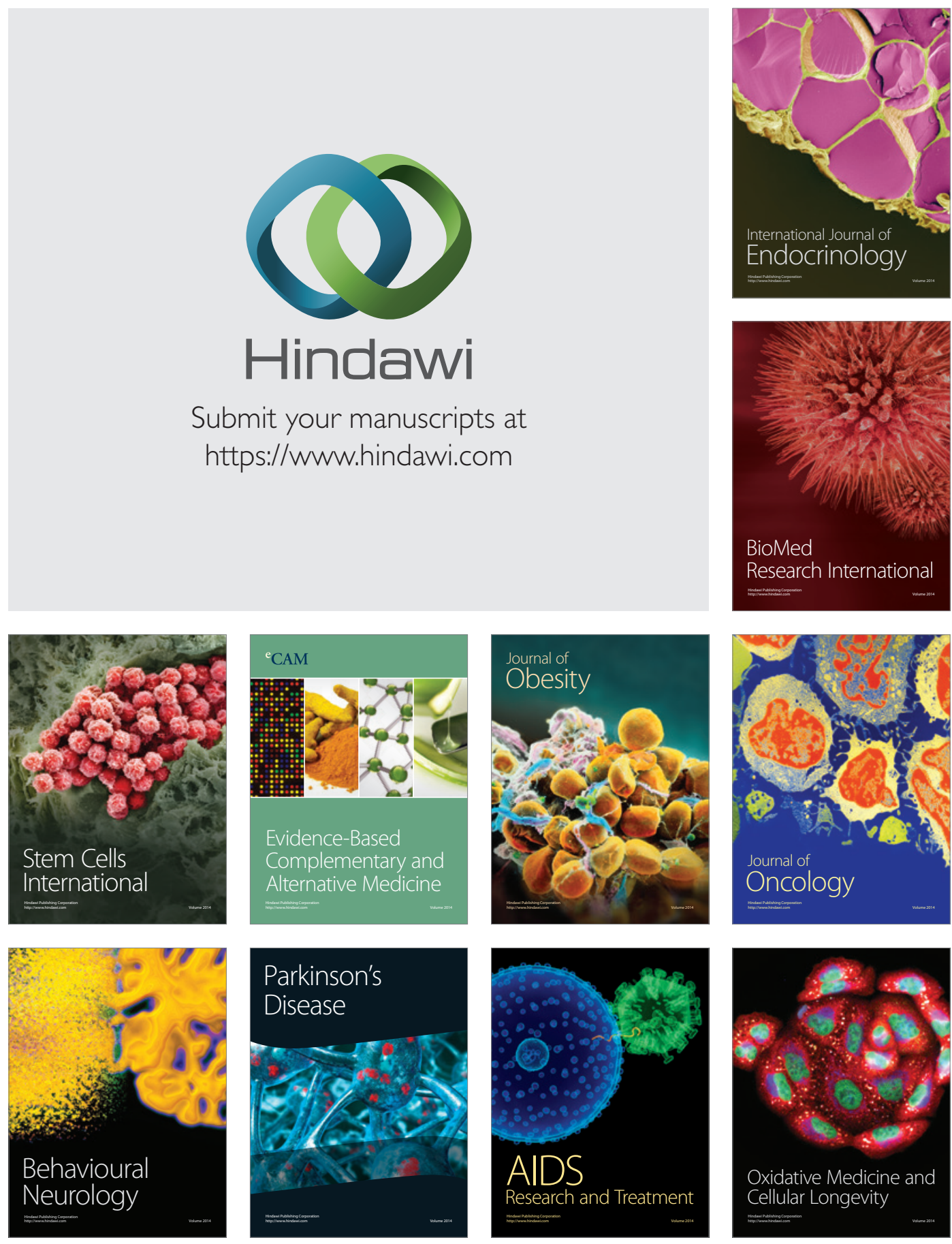